\section{Review of the Symbiotic Genus Haplosyllides (Polychaeta: Syllidae), with a Description of a New Species}

Daniel Martin ${ }^{1 *}$, Maria Teresa Aguado ${ }^{2}$ and Temir A. Britayev ${ }^{3}$

'Centre d'Estudis Avançats de Blanes (CSIC), Carrer d'accés a la cala Sant Francesc 14, 17300 Blanes (Girona), Catalunya, Spain

${ }^{2}$ Laboratorio de Biología Marina, Facultad de Ciencias (Biológicas), Universidad Autónoma de Madrid, Cantoblanco, 28049, Madrid, Spain

${ }^{3}$ A.N. Severtzov Institute of Ecology and Evolution (RAS), Leninsky pr. 33, 117071 Moscow, Russia

Abbreviated title: Review of Symbiotic Haplosyllides

*Corresponding author

Phone: +34972336101

Fax: +349726806

E-mail: dani@ceab.csic.es
Martin, D. Aguado, M. T. \& Britayev, T. A. (2009) Review of the symbiotic genus Haplosyllides (Polychaeta, Syllidae), with description of a new species. Zoological Science 26: 646-655.

\section{ABSTRACT}

The genus Haplosyllides was considered as monotypic, with H. floridana as the only valid species. The present revision includes two more species in this genus: H. aberrans comb. nov. and H. ophiocomae sp. nov. Syllis (Haplosyllis) aberrans (from Vietnam) was considered a junior synonym of $H$. floridana (from the Caribbean). The finding of additional specimens from Vietnam and Indonesia, and the study of the type series, allowed us to redescribe $H$. aberrans comb. nov. on the basis of morphological, ecological and biogeographical characteristics. Haplosyllides aberrans comb. nov. differs from H. floridana in having posterior simple chaetae with tips twice as long, a pharyngeal tooth in all non-reproductive individuals, and the granules inside the dorsal cirri oval, elongated, and roughly distributed in longitudinal parallel rows. Haplosyllides ophiocomae sp. nov. was previously reported (as $H$. aberrans) from Puerto Rico. Although geographically close, it differs from H. floridana in having serration on the upper edge of the major teeth of simple chaetae, relatively shorter dorsal cirri, and a distinct mode of life. Haplosyllides floridana lives as an endosimbiont of Xetospongia muta, $\mathrm{H}$. aberrans comb. nov. as a facultative parasite of Platycaris latirostris, and H. ophiocomae sp. nov. as a commensal of Ophiocoma pumila and other brittle stars. The meaning of these associations is discussed in light of the available information. The remaining records of "Haplosyllides aberrans" from the Marshall Islands (associated with corals of the genus Heliopora) and from Brazil (among corals and calcareous algae) are considered as doubtful.

Key words: Vietnam, Indonesia, Cuba, Puerto Rico, taxonomic review, symbiotic species, Haplosyllides, Polychaeta 


\section{INTRODUCTION}

The genus Haplosyllides was considered monotypic after Uebelacker (1982) synonymized Syllis (Haplosyllis) aberrans Fauvel, 1939 from Vietnam with Haplosyllides floridana Augener, 1924 from Florida. This synonymy also included all previous records of Haplosyllis aberrans by Hartman (1954), Hartmann-Schröder (1978), and Rullier and Amoureux (Rullier and Amoureux, 1979). It was then validated by San Martín et al. (1997), who re-described H. floridana based on material from Cuba, living as endosymbionts of the sponge Xetospongia muta (De Laubenfels, 1930), without checking Fauvel's Vietnamese material.

During a survey of the fauna associated with the scleractinian coral Galaxea astreata (Lamarck, 1816) in Nhatrang Bay, Vietnam (Marin, in prep.), the same area from where Syllis (Haplosyllis) aberrans was described (Fauvel, 1939), a specimen was found attached to the base of a pleopod of the symbiotic pontoniin shrimp Platycaris latirostris Holthuis, 1952. Careful observations revealed that this specimen belonged to the genus Haplosyllides, like several additional specimens found within the collections of the Siboga (1899) and Snellius II (1984) expeditions to Indonesian waters. The study of Fauvel's syntypes of Syllis (Haplosyllis) aberrans (Musée National d'Histoire Naturelle, Paris; MNHNP), the holotype of Haplosyllides floridana (Zoologisches Museum, Museum für Naturkunde, Berlin; ZMB), and a large collection of H. floridana from Cuba (Museo Nacional de Ciencias Naturales, Madrid; MNCNM) led us to demonstrate that, in addition to differing biogeographically and ecologically, Vietnamese/Indonesian specimens also differed morphologically from Cuban/Floridian specimens. Consequently, the former are here re-described as Haplosyllides aberrans comb. nov.

Specimens of Haplosyllis aberrans collected by M. Youngbluth in Tortuguero (Puerto Rico) and reported as commensal with the brittle star Ophiocoma pumila Lütken, 1859 by Hartmann-Schröder (1978) were analyzed on the basis of the original description and the collections of the Zoologisches Institut und Zoologisches Museum of Hamburg University (ZMH) and the Bernice P. Bishop Museum (BPBM). Our observations on the morphological peculiarities of these specimens, which fully agree with the original description by HartmannSchröder (1978), together with the apparent specificity of its life-habit, led us to describe a new species, Haplosyllides ophiocomae.
Martin, D. Aguado, M. T. \& Britayev, T. A. (2009) Review of the symbiotic genus Haplosyllides (Polychaeta, Syllidae), with description of a new species. Zoological Science 26: 646-655.

\section{MATERIALS AND METHODS}

The parasitic Vietnamese specimen was collected by I. Marin at Mung Island, Nhatrang Bay (2003). It is deposited with the collections of the MNHNP. The specimens from Indonesia were collected during the Siboga Expedition in 1899 and the Snelius II Expedition in 1984. They are deposited in the collections of the Zoologisch Museum, Universiteit van Amsterdam (ZMA). All specimens were fixed in 10\% formaldehyde-seawater and preserved in $70 \%$ alcohol. The specimens from the BPBM were all dried. To allow observations, they were first submerged in a mixture of distilled water and neutral soap until rehydrated and then preserved in $70 \%$ alcohol.

For light microscope (LM) observations, the specimens were directly placed on slides in a solution of glycerine and distilled water. LM drawings were made with a Nikon Optiphotoptic compound microscope equipped with a camera lucida and interference contrast (Nomarsky) optics. LM micrographs were made with a ProgRes C10 Plus digital camera (Jenoptics, Jena) attached to a Zeiss Stemi 2000-C compound microscope. The width of the specimens was measured at the proventricle level, without parapodia. To avoid any possible size-related bias when comparing the length pattern of the dorsal cirri, all lengths were standardized by dividing them by the length of the longest first dorsal cirrus. All measurements were an average of three specimens. Appendage length patterns for $H$. floridana and $H$. aberrans comb. nov. were compared by means of the paired t-test using SYSTAT 5.2.1 software (SYSTAT, 1990-92).

For observations with a scanning electron microscope (SEM), selected specimens of Haplosyllides aberrans comb. nov., H. floridana, and H. ophiocomae sp. nov. were run through a series of increasing ethanol concentrations and stored in $90 \%$ ethanol until observation. Immediately prior to viewing, they were transferred to $100 \%$ alcohol, air-dried, mounted on a grid with double-sided sticky tape, attached to a stub, and coated with gold palladium.

The type series of Haplosyllis floridana and Syllis (Haplosyllis) aberrans were loaned by ZMB and MNHNP, respectively. Haplosylides floridana from Cuba was loaned by MNCNM, and the materials currently assigned to H. ophiocomae sp. nov. were loaned by $\mathrm{ZMH}$ and BPBM. 


\section{TAXONOMIC ACCOUNTS}

\section{Haplosyllides aberrans (Fauvel, 1939) comb. nov.}

(Figs. 1-7)

Syllis (Haplosyllis) aberrans - Fauvel, 1939: p. 290, 291, fig. 3.

Haplosyllides floridana - Uebelacker, 1982: p. 585 (partim); San Martín et al. 1997: p. 366378 (partim).

Type locality. South China Sea, Vietnam, Cauda and Spratly Reefs.

Material examined. MNHNP POLY TYPE 0733, as syntypes, Vietnam. Two specimens from South China Sea, Vietnam, Cauda and Spratly Reefs; collected by M.C. Dawydoff. MNHNP TYPE 1497, as paratype: one specimen from South China Sea, Vietnam, Nhatrang Bay, Mung Island, 2-3 m deep, attached to Platycaris latirostris; collected by I. Marin, October 6, 2003. ZMA V.Pol. 2046: 2 specimens from Indonesia, Anchorage off Pulu Tongkil Sulu archipelago, $6^{\circ} 04^{\prime} \mathrm{N}, 121^{\circ} 45^{\prime} \mathrm{E}$, St. $109,13 \mathrm{~m}$ deep; collected during the Siboga Expedition, June 5-6, 1899. ZMA V.Pol. 5271, four specimens from Indonesia ZMA V.Pol. 5271, NE coast of Sumba, $09^{\circ} 57^{\prime} \mathrm{S} 120^{\circ} 48^{\prime} \mathrm{E}$, sandy bottom with sponges and gorgonians, St. 4.068, $50 \mathrm{~m}$ deep, $1.2 \mathrm{~m}$ Agassiz trawl; collected by H. A. Ten Hove during the Snellius II Expedition, September 16, 1984

Description. Syntype. Complete specimen, $5.37 \mathrm{~mm}$ long, maximum width excluding parapodia $0.61 \mathrm{~mm}$, with 26 chaetigers (MNHNP POLY TYPE 0733). Body short, maximum thickness in the area of proventricle (Figs. 1A, 3A), gradually tapering posteriorly (Fig. 3D), without color, translucent epidermis with small granules (Figs. 1C, 3C). Borders between segments invisible in anterior region (proventricle and anterior intestine area) and well marked by intersegmental furrows posteriorly. Prostomium oval, with one pair of small brown eyes located posterolaterally (Fig. 1A).

Median antennae attached medially at posterior hind of prostomium, very long (1.62 $\mathrm{mm})$, about three times the length of lateral antennae $(0.55 \mathrm{~mm})$. Lateral antennae attached anterolaterally to eyes. Palps similar in length to prostomium, fused at bases, broadly attached to prostomium (Figs. 1A, 3A, 3B). Two pairs of tentacular cirri, dorsal ones three times as long as ventral ones, but shorter than lateral antennae and dorsal cirri of first chaetiger (Figs. 1A, 3A). Ventral tentacular cirri cirriform with attenuated tip, without basal enlargement.
Martin, D. Aguado, M. T. \& Britayev, T. A. (2009) Review of the symbiotic genus Haplosyllides (Polychaeta, Syllidae), with description of a new species. Zoological Science 26: 646-655,

Antennae, tentacular and dorsal cirri smooth, non-articulated, slender and tapering to filiform tips (Figs. 1A, 3A). Parapodia conical, provided distally with two small lateral lobes (Fig 1C). Parapodia and cirri with oval elongated granules roughly distributed in longitudinal parallel rows in dorsal cirri (Figs. 1C, 7B); dorsal cirri alternating long and short according to following arrangement: chaetiger 1 long (L, $1.23 \mathrm{~mm}), 2$ and 3 short $(\mathrm{S}, 0.47-0.40 \mathrm{~mm}), 4 \mathrm{~L}$ $(0.99 \mathrm{~mm}), 5$ and $6 \mathrm{~S}(0.51-0.28 \mathrm{~mm}), 7 \mathrm{~L}(0.70 \mathrm{~mm})$, then alternating $8 \mathrm{~S}(0.22 \mathrm{~mm}), 9 \mathrm{~L}$ $(0.57 \mathrm{~mm}), 10 \mathrm{~S}(0.24 \mathrm{~mm}), 11 \mathrm{~L}(0.63 \mathrm{~mm}), 12 \mathrm{~S}(0.23 \mathrm{~mm}), 13 \mathrm{~L}(0,59 \mathrm{~mm})$, and $14 \mathrm{~S}$ $(0.31 \mathrm{~mm})$, then $15 \mathrm{~S}(0.28 \mathrm{~mm}), 16 \mathrm{~L}(0.35 \mathrm{~mm}), 17 \mathrm{~S}(0.28 \mathrm{~mm})$, and $18 \mathrm{~L}(0.68 \mathrm{~mm})$. Cirri from posterior-most chaetigers ranging from $0.1-0.26 \mathrm{~mm}(\mathrm{~S})$ and $0.31-0.39 \mathrm{~mm}(\mathrm{~L})$ in length. Ventral cirri cirriform, with attenuated tips, smooth, slightly shorter than or equal to parapodial lobes in length (Fig. 1C). Two (occasionally three) thick simple chaetae on each parapodium, usually one thicker than the others; all with tridentate curved tips and sub-distal constrictions at different levels (Figs. 2E-H, 5D-F). Posterior-most chaetae (Figs. 2F, 2H, 5F) more elongated than anterior-most (Figs. 2E, 2G, 5D). Distance between chaetal tip and subdistal constriction (distance a, Fig 2) $3.2 \pm 0.2$ as long as width of chaetal apex (distance b, Fig. 2). One aciculum per parapodium (occasionally two on the posterior-most), straight, with truncated tip, similar in width to the thicker chaetae (Fig. 1C).

Pharynx similar in length to proventricle $(0.74 \mathrm{~mm})$, with an anterior pharyngeal tooth, bearing a crown of 10-12 distal papillae and a distal ring of cilia (Fig. 4B). Pharyngeal papillae with pores of two sizes (Fig. 4D). Proventricle short, $0.71 \mathrm{~mm}$ long by $0.36 \mathrm{~mm}$ wide, extending from chaetiger 2 to the end of chaetiger 4, with 31 muscle cell rows (Figs. 1A, 3E, 3F). Pygidium small, rounded. Two anal cirri, absent in one of the syntypes, but similar in length to the long posterior-most dorsal cirri in the other specimens (Fig. 3D).

Remarks. Morphometric variation in the specimens studied is summarized in Table 1. Haplosyllides aberrans comb. nov. from Vietnam and Indonesia differs slightly but significantly from the Caribbean specimens of H. floridana. Both species had two similar simple chaetae per parapodium, occasionally three in $H$. aberrans comb. nov., but these were less robust and the tips were half as long in the latter as in the former (Figs. 2, 5).

San Martín et al. (1997) found two different forms in the material studied from Cuba: non-reproductive individuals (form A, MNCNM 16.01/8810) and specimens with attached sexual stolons (form B, MNCNM 16.01/8808). Form A lacked a pharyngeal tooth (present in form B) and had a longer proventricle than form B; however, both forms had similar chaetal shapes (Fig. 2A-D). Conversely, all nine known specimens of H. aberrans comb. nov. were 
morphologically similar, having a pharyngeal tooth and insignificant variation in proventricle shape. Only one specimen (ZMA V.Pol. 5271) had slightly shorter anterior chaetae (Fig. 2G) than was typical (Figs. 2E, F, 5B, D, F), and thus more similar to the chaetae of H. floridana (Fig. 2A-D). However, the posterior chaetae were slender and longer (Fig. 2H), similar to the typical form (Figs. 2E, F, 5B, D, F). This variability in the anterior-most chaetae allows us to assume that differences in chaetal arrangement between the two species are more reliably detected in the posterior-most chaetae. The particular shape of the chaetae, with a subdistal enlargement separating the distal tip from the chaetal shaft, may be viewed as additional support for the hypothesis that the simple chaetae in Haplosyllides originated by fusion of the blade and shaft of a typical articulate syllid chaeta. This hypothesis was postulated for two species of Haplosyllis, H. anthogorgicola Utinomi, 1939 (Martin et al., 2002) and H. loboi (Paola et al., 2006), where possible origins by loss of the blade of compound falcigers or by evolution of the simple chaetae "de novo" were rejected in favor of the fusion hypothesis.

In addition to the chaetal differences, the muscular cells of the proventricle in $H$. floridana were more quadrangular in shape, and the granules inside the body were less prominent than in H. aberrans comb. nov. Moreover, there were 10-12 pharyngeal papillae in H. aberrans comb. nov. and only 10 in H. floridana (Fig. 4A, B). However, there were no differences in the sensory organs of the respective pharyngeal papillae (Fig. 4C, D). In general, all body measurements were, on average, longer in H. aberrans than in H. floridana, except for the proventricle width and the length of tentacular and anal cirri (Table 1). Conversely, when comparable, the lengths of dorsal cirri tended to be significantly shorter ( $t$ test, $\mathrm{t}=4.05 ; \mathrm{p}<0.001$ ) in H. aberrans comb. nov. than in H. floridana (Fig. 6). Finally, the granules inside the dorsal cirri were oval, elongated, and roughly distributed in longitudinal parallel rows (Fig. 7B, D) in H. aberrans comb. nov., and round and randomly distributed in H. floridana (Fig. 7G).

In summary, we consider the morphological differences (together with the ecological ones, see below) between the material from distant geographical areas (Caribbean Sea vs. Vietnam and Indonesia) to be sufficient to allocate them into different species, respectively: i) Haplosyllides floridana sensu Augener (1924) and, partly, San Martín et al. (1997); ii) Haplosyllides aberrans, a new combination for the originally described Syllis (Haplosyllis) aberrans by Fauvel (1939).

Distribution. Nhatrang Bay and Spratly Archipelago, Vietnam, South China Sea; NE coast of Sumba and Pulu Tongkil, Sulu archipelago, Indonesia.
Martin, D. Aguado, M. T. \& Britayev, T. A. (2009) Review of the symbiotic genus Haplosyllides (Polychaeta, Syllidae), with description of a new species. Zoological Science 26: 646-655.

Ecology. Specimen MNHNP TYPE 1497 was found at Mung Island (coast of Vietnam, South China Sea), at 2-3 m deep, attached to a pleopod of a female specimen of the pontoniin shrimp Platycaris latirostris, an obligatory associate of the scleractinian coral Galaxea astreata (Martin et al., 2008). Specimens from Indonesia were found with sponges and gorgonians on sandy bottoms $13-50 \mathrm{~m}$ deep; however, these organisms were only reported as accompanying fauna and there was no mention of a possible specific association with $H$. aberrans.

\section{Haplosyllides floridana Augener, 1924}

(Figs. 2, 4-7)

Haplosyllides floridana - Augener, 1924: p. 44; San Martín et al. 1997: p. 366-378, Figs. 1-3 (partim).

Haplosyllis floridana - Uabelacker, 1982: p. 585, fig. 1, (partim). San Martín et al. 1997: p. 366-378, Figs. 1-3.

Material examined. Haplosyllides floridana. Holotype (ZMB 6608), Tortugas. Hundreds of specimens from the Caribbean Sea (MNCNM 16.01/8806, 8808, 8809, 8810) Cuba, off La Habana, $5 \mathrm{~m}$ deept, living inside the sponge Xetospongia muta, collected and identified by G. San Martín in June1992, July and October 1993 and January and April 1994.

Diagnosis. Modified from San Martín et al. (1997). Body small with few chaetigers, epidermis translucent with small granules. Segments without intersegmental furrows. Prostomium with two eyes and three antennae, median one very long. Palps fused to a single, anteriorly bilobed piece. Two pairs of tentacular cirri, ventral ones considerably shorter than dorsal pair. Antennae, tentacular, and dorsal cirri smooth, slender and filiform. Parapodia and cirri with round, randomly distributed granules. First dorsal cirri long, 2nd and 3rd shorter than both 1st cirri and body width; 4th long, 5th and 6th short; remaining cirri alternating in length. Dorsal cirri of posterior end short, all similar in length. Parapodia conical, with two small lateral lobes and one more dorsally located. Two thick simple chaetae on each parapodium, with two small distal teeth, and one distal tooth more laterally located. Distance between chaetal tip and subdistal constriction (distance a, Fig. 2) $1.6 \pm 0.2$ as long as width of chaetal apex (distance b, Fig. 2). Acicula solitary, straight, distally truncate. Pharynx with a 
distal crown of 10 papillae and a ring of cilia. Pharyngeal tooth present only on small specimens, at anterior end of pharynx. Proventricle long (2.5-5 chaetigers) on larger specimens, short (less than 2.5 chaetigers) on smaller. Pygidium small, rounded, with two anal cirri, similar in shape and length to longest dorsal cirri. Morphometric variation in the specimens studied is summarized in Table 1.

Distribution. Florida, Tortugas, Cuba

Ecology. Haplosyllides floridana was described on the basis of a swimming male stolon (Holotype ZMB 6608) and then fully re-described as an exclusive endosymbiont of the sponge Xetospongia muta from Cuba (San Martín et al., 1997). Several thousands or millions of worms inhabited the aquiferous system of the host. Haplosyllides floridana seemed to spend most of its life cycle inside the host sponge. All different reproductive phases were found as endosymbionts (from young juveniles to female epitokous forms, including large asexual specimens), with the exception of male stolons (which seemed to be free swimmers). No additional information on the exact nature of the relationships with the host was provided, and it is unclear whether the species should be considered a parasite or a commensal.

\section{Haplosyllides ophiocomae sp. nov.}

(Figs. 6, 8-10)

Haplosyllis aberrans - Hartman-Schröder, 1978: p. 49-53, Figs. 1-7.

Type locality. Tortuguero, Puerto Rico.

Type material. Holotype ZMH P-22072, one specimen collected by M. Youngbluth on January 29, 1973, 15 m deep, associated with Ophiocoma pumila. Paratype BPBM-R 917, one specimen collected by M. Youngbluth on January 29, 1973, 15 m deep, associated with Ophiocoma pumila. Paratypes BPBM-R 917, 10 specimens collected by M. Youngbluth on January 29, 1973, 15 m deep, associated with Ophiocoma pumila and other brittle stars.

Description. Holoype a complete specimen, $1.87 \mathrm{~mm}$ long, maximum width excluding parapodia $0.24 \mathrm{~mm}$, with 12 chaetigers. Body short, maximum thickness around proventricle, gradually tapering posteriorly, colorless; translucent epidermis with small, round granules (Fig. 9A). Borders between anterior-most segments not well marked, except between prostomium and first chaetiger. Prostomium oval, with one pair of small, brownish eyespots (difficult to see on holotype due to long-term preservation) located anterolaterally near the
Martin, D. Aguado, M. \& \& Britayev, T. A. (2009) Review of the symbiotic genus Haplosyllides (Polychaeta, Syllidae), with description of a new species. Zoological Science 26: 646-655.

bases of lateral antennae (Fig. 8C). Morphometric variation in the specimens studied is summarized in Table 1.

Median antennae attached medially on posterior of prostomium (Figs. 8C, 10A), very long $(0.71 \mathrm{~mm})$, about three times as long as lateral antennae $(0.23 \mathrm{~mm})$. Lateral antennae attached anterolaterally to eyes, near the bases of palps. Palps similar in length to prostomium, fused at bases, without a clear distinction from the anterior prostomium edge (Fig. 8C). Two pairs of tentacular cirri, dorsal ones three times as long as ventral ones $(0.21$ and $0.07 \mathrm{~mm}$ respectively), but shorter than lateral antennae and first dorsal cirri (Table 1). Antennae, and tentacular and dorsal cirri smooth, non-articulated, slender, tapering to filiform tips (Figs. 8C, 9A, 10A). Parapodia conical, with two small lateral lobes distally (Fig. 8C). Parapodia and dorsal cirri with round granules distributed at random (Fig. 9D). Dorsal cirri alternating long and short, according to following arrangement: chaetiger 1 long $(\mathrm{L}, 0.55 \mathrm{~mm}), 2$ and 3 short $(\mathrm{S}, 0.20-0.14 \mathrm{~mm}), 4 \mathrm{~L}(0.30 \mathrm{~mm}), 5$ and $6 \mathrm{~S}(0.13-0.14 \mathrm{~mm}), 7 \mathrm{~L}(0.29 \mathrm{~mm}), 8 \mathrm{~S}(0.14 \mathrm{~mm})$, $9 \mathrm{~L}(0.25 \mathrm{~mm}), 10 \mathrm{~S}(0.10-0.16 \mathrm{~mm})$, and $11 \mathrm{~L}(0.12-0.21 \mathrm{~mm})$ (Table 1). Ventral cirri cirriform, with attenuated tips, smooth, slightly shorter than or equal to parapodial lobes in length.

Two (occasionally three) thick simple chaetae on each parapodium, one usually thicker; all with tridentate curved tips, with serration on upper edge of largest teeth, more clearly visible under light microscope than under SEM, and in mid-body and posterior most chaetae, with subdistal constrictions at different levels (Figs. 8A, E-H, 9C, 10C-G). Distance between chaetal tip and subdistal constriction (distance a, Fig. 2) $1.9 \pm 0.2$ as long as width of chaetal apex (distance b, Fig. 2). One aciculum per parapodium (occasionally two on the posterior-most), straight, with pointed, oblique tip, similar in width to the thicker chaetae (Figs. 8B, 9B).

Pharynx slightly longer than proventricle $(0.33 \mathrm{~mm})$, with an anterior pharyngeal tooth, bearing a distal ring of cilia and a crown of 11 or 12 distal papillae (Fig. 10B); sensory organs on papillae not seen. Proventricle short, $0.27 \mathrm{~mm}$ long by $0.18 \mathrm{~mm}$ wide, extending from chaetiger 2 to the end of chaetiger 4, with 22 muscle cell rows (Fig. 9A). Pygidium small, rounded. Two anal cirri, similar in length to longest dorsal cirri $(0.37 \mathrm{~mm})$ (Fig. 9A).

Remarks. Haplosyllides ophiocomae sp. nov. closely resembled H. aberrans comb. nov. and H. floridana. Since the holotype seemed to be a young specimen, the body and appendage measurements fell within the range of variation in the other two species (Table 1 , Fig. 6), and the chaetae were also similar in shape, size, and number (two per parapodium, 
occasionally three as in H. aberrans comb. nov.). However, the chaetae in H. ophiocomae sp. nov. were intermediate, both in thickness and tip length. Additionally, the serration evident on the upper edge of the major teeth, previously observed and illustrated by Hartmann-Schröder (1978) (Fig. 8E-H) and clearly visible under the light microscope (Fig. 9C) and with difficulty by SEM (Fig. 10E, G), was absent in the other two species.

Granules were very abundant in the body and appendages of $H$. ophiocomae sp. nov., especially in the appendages, where they were round and distributed at random as in $H$. floridana. The holotype had 11 pharyngeal papillae, but the range was the same as in the BPBM specimens of H. aberrans comb. nov. with everted pharynx. The central antennae of the holotype were about twice as long as the lateral ones, as in H. floridana, but the larger specimen described by Hartmann-Schröder (1978) had a central antennae more than three times as long as the lateral ones, longer even than in H. aberrans. Only three specimens in the BPBM had antennae: one was likely the same illustrated by Hartmann-Schröder (1978), the other had the central antennae broken (Fig. 10A), and the third was a relatively small worm, with central antennae about three times as long as the lateral ones. All the remaining appendages were relatively shorter than in H. floridana and H. aberrans comb. nov., except for the ventral tentacular cirri (equal to those in H. aberrans comb. nov.) and anal cirri (longer than in H. aberrans comb. nov.). The proventricle was also shorter than in the other two species, although the width/length ratio was closer to that in H. floridana. In turn, the pharynx was intermediate in length (shorter than in H. aberrans comb. nov. and longer than in $H$. floridana). Due to insufficient specimens, it was not possible to assess whether the specimens of H. ophiocomae sp. nov. had uniform morphology (as in H. aberrans comb. nov.) or had two morphologies (as in H. floridana).

The geographical differences between $H$. ophiocomae sp. nov. and H. floridana are not as marked as those between these species and H. aberrans comb. nov. However, we consider that the observed morphological differences (particularly clear in the length pattern of dorsal cirri and chaetal shape), together with the ecological differences (but see Discussion), in material between Puerto Rico and Cuba are sufficient to validate the description of the former as a new species.

Distribution. Tortuguero, Puerto Rico.

Ecology. Living in symbiosis (commensalism?) with Ophiocoma pumila and other brittle stars.
Martin, D. Aguado, M. T. \& Britayev, T. A. (2009) Review of the symbiotic genus Haplosyllides (Polychaeta, Syllidae), with description of a new species. Zoological Science 26: 646-655.

\section{DISCUSSION}

In their review of symbiotic polychaetes, Martin and Britayev (1998) reported on about 20 different syllid genera that include symbiotic species. Since then, there have been major improvements in the knowledge of symbiotic syllids, the most significant dealing with two genera closely related to Haplosyllides, Haplosyllis Langerhans. 1879 and Alcyonosyllis Glasby \& Watson, 2001

In Haplosyllis, recent studies have demonstrated that the widespread sponge symbiont H. spongicola (Grube, 1875) corresponds, in fact, to a species complex whose components are often restricted in biogeographical distribution and show marked host specificity (Martin et al., 2003; Lattig et al., 2007). This certainly applies the Caribbean and Indopacific regions, where most previous records of $H$. spongicola must be viewed with caution, as they may correspond to different, likely new species: for instance, records from the Bahamas, Barbados, USA (Florida), and Jamaica and Puerto Rico (Bacescu, 1971; Dauer, 1973; Reiswig, 1973; Dauer, 1974; Uebelacker, 1978; Humann, 1992; Tsurumi and Reiswig, 1997; Maldonado and Young, 1998b; a; López et al., 2001), and those from Cambodia and Vietnam (López et al., 2001), Korea (Lee and Rho, 1994), Japan (Imajima and Hartman, 1964; Imajima, 1966; 2003), Tanzania (Magnino and Gaino, 1998), and Papua New Guinea (Magnino et al., 1999).

Alcyonosyllis was initially defined as comprising strict octocoral symbionts, based on A. phili from Australia and Papua New Guinea (Glasby and Watson, 2001). An Indopacific distribution, as well as host specificity, has been attributed to all new species currently included in the genus, including A. glasby recently described from Japan (San Martín and Nishi, 2003) and species formerly assigned to Haplosyllis inhabiting Japanese and Indonesian waters: A. xeniaecola (Hartmann-Schröder, 1993), A. onkylochaeta (Hartmann-Schröder, 1991) and A. exiliformis (Imajima, 2003) (Glasby and Watson, 2001; San Martín and Nishi, 2003).

The biogeography and specific peculiarities of the mode of life of symbiotic syllids thus have an intrinsic interest, and this certainly applies to Haplosyllides and its previously known representatives, H. floridana (an exclusive endosymbiont of the sponge Xetospongia muta from the Caribbean Sea) and $H$. aberrans comb. nov. (a facultative parasitic hypersymbiont - symbiont of a symbiont - of the shrimp Platycaris latirostris, associated with the coral Galaxea astreata in Vietnamese and Indonesian waters). These differences 
triggered the present revision and proved to be excellent support for the taxonomic distinction between these species early synonymized by Uebelacker (1982) and San Martín et al. (1997). Moreover, our review also led us to study material corresponding to another population from the Caribbean, reported by Hartman-Schröder (1978) to be commensal on the brittle star Ophiocoma pumilla, that is here described as a third, new species in the genus. Although the differences in ecology and behavior among the three species of Haplosyllides appeared to be clear, analysis of the BPBM material for H. ophiocomae sp. nov. cast some doubts on the previously reported information

The ecology and behavior of Haplosyllides floridana seem to be well defined. There is no doubt that this species lives in dense aggregates as an endosymbiont of its host sponge, despite the initial discovery of the species as a swimming specimen (in this case a male epitoke). In contrast, knowledge of the mode of life of H. aberrans comb. nov. is fragmental, contradictory, and to some extent enigmatic. The specimens described by Fauvel (1939) were collected by Dawydoff with the help of a light trap, demonstrating the ability of the worms to swim, even if there were no epitokes. Whether this swimming capacity is related to the ability to parasitize shrimps reported by Martin et al. (2008) is certainly a matter of speculation. Moreover, there are no data on the habitat or on how this species was collected during the Siboga Expedition. The specimens collected during the Snellius II Expedition were found "among sandy bottoms with sponges and gorgonians", which lacks enough precision to provide additional data on the behavioral specificity of this population.

Although Hartman-Schröder (1978) did not provide enough detailed ecological information on Haplosyllides ophiocomae sp. nov., she considered the species to be a specific commensal of Ophiocoma pumilla. However, according to the original label included in the BPBM loan (Fig. 10), the worms were collected not only from this brittle star, but also from "other ophiuroids", which was not mentioned in the 1978 paper. Although these additional hosts were not identified, they could have belonged to various species, and thus the postulated association might not be species specific.

In fact, the finding of Haplosyllides aberrans as a parasite of Platicaris latirostris (Martin et al., 2008) triggered an exchange of information between the first author (D. Martin) and Dr. Leslie Harris (from the Natural History Museum of Los Angeles County), who kindly offered us her accurate observations and knowledge on living sponge endosymbiotic specimens of Haplosyllides and the closely related genus Haplosyllis from the Caribbean and Hawaiian regions. These worms always remain inside their host sponges, but once disturbed
Martin, D. Aguado, M. T. \& Britayev, T. A. (2009) Review of the symbiotic genus Haplosyllides (Polychaeta, Syllidae), with description of a new species. Zoological Science 26: 646-655.

(e.g., by reducing the oxygen availability in the surrounding water), they rapidly emerge from the sponges and immediately start to evert and retract the pharynx. If the pharynx contacts the surface of any other organism (e.g., other polychaetes, molluscs, crustaceans, tunicates, bryozoans, anemones, brittle stars, or echinoids), the proventricle automatically starts to pump, and the worms are able to remain attached to these organisms through the pharynx, even sucking their tissues.

As in many free-living polychaetes (such as phyllodocids or glycerids, D. Martin, personal observations) when collected and left "in vivo" out of the sediment, these pharyngeal movements may certainly be an accidental response caused by the stress of being out of the host. Alternatively, however, this may also be a normal component of the life cycle, where behavioral elements of free living polychaetes have been specifically integrated into a symbiotic mode of life, as previously reported for other symbionts such as the nereidid polychaete Nereis fucata (Gilpin-Brown, 1969; Cram and Evans, 1980). If so, the pharyngeal movements may be helpful in two situations.

The first could be finding and maintaining an attachment to a temporary or intermediate host, as in the case of Haplosyllides aberrans comb. nov. and Platycaris latirostris, where tissues from the shrimp were seen deep inside the gut of the syllid and the pleopod was consequently reduced (Martin et al., 2008). Although it seems quite evident that H. aberrans comb. nov. was feeding on the shrimp, whether this intermediate host provides simple support (with the tissues inside the gut resulting from automatic pumping of the proventricle) or an additional food source is difficult to confirm without specific experiments.

The second situation was also suggested by Dr. Harris, who addressed us in a web forum on sea slugs to demonstrate that endosymbiotic syllids (likely Haplosyllis, but also perhaps Haplosyllides) were able to effectively defend their host sponges against attacks from spongivorous nudibranchs of the genus Hypselodoris by protruding from the host sponge and repeatedly biting the intruder with the help of the pharynx (see Imamoto, 2002; Rudman, 2002; Velarde, 2002; Harris, 2006; Rudman, 2006). In this case, the pharyngeal movements may be an intrinsic part of the mode of life of the symbiont, but they are certainly interesting for the host too, suggesting a mutualistic rather than a commensalistic association, which may also be the case for Haplosyllides floridana.

In summary, although Haplosyllides was considered monotypic after Uebelacker (1982) and San Martín et al. (1997), the present review differentiates two previously synonymized species ( $H$. floridana and $H$. aberrans comb. nov.) and describes $H$. 
ophiocomae sp. nov. through a careful classical morphological approach, supported by biogeographical and, to some extent, ecological/behavioral features. The peculiarities of the respective associations of the three Haplosyllis species, although poorly known at present, are certainly an interesting topic for further study. Moreover, on the whole, our review also casts some doubt on all remaining " $H$. aberrans" populations previously reported. In particular, the populations in the Marshall Islands, associated with corals of the genus Heliopora (Hartman, 1954), and in Brazil, found within corals and calcareous algae (Rullier and Amoureux, 1979), were only mentioned in the previous papers, without formal description or additional data on ecology and behavior. As it has not been possible to obtain reference material to check the status of these populations, their taxonomic assessment also remains open to future research.

\section{ACKNOWLEDGMENTS}

We thank Dr. Guillermo San Martín for fruitful discussions on the genus Haplosyllides and its morphological variability; Dr. Harry A. Ten Hove for collecting polychaetes during the Snellius II Expedition and providing the syllids from the Siboga Expedition; Birger Neuhaus (ZMB), Tarik Meziane (MNHNP), Miguel Villena (MNCNM), Angelika Brand (ZMH), and Holly Bolick (BPBM) for loaning the holotype of Haplosyllides floridana, the type series of H. aberrans comb. nov., specimens of H. floridana from Cuba, and specimens of H. ophiocomae sp. nov., respectively; and the staff of the SEM service at the Institute of Marine Sciences of Barcelona and at the Servicio Interdepartamental de Investigación of the Universidad Autónoma of Madrid for help with sample treatment and observation. This study was financed by the European Commission's Research Infrastructure Action via the SYNTHESYS Project, and partially supported by the project "Taxonomía y Sistemática de la Familia Syllidae (Polychaeta)" (CGL2005-02442), financed by the Ministerio de Educación y Ciencia of Spain and by the Russian Foundation for Basic Research (08-04-92244-GFEN and 09-05-00736-a).

\section{REFERENCES}

Augener H (1924) Über litorale polychäten von Westindien. Sitz Ges Naturf Freunde Berlin 1922: 38-5
Martin, D. Aguado, M. T. \& Britayev, T. A. (2009) Review of the symbiotic genus Haplosyllides (Polychaeta, Syllidae), with description of a new species. Zoological Science 26: 646-655.

Bacescu M (1971) Les Spongiaires: un des plus intéressants biotopes benthiques marins. Rapp Comm Int Mer Medit 20: 239-241

Cram A, Evans SM (1980) Shell entry behaviour in the commensal ragworm Nereis fucata. Mar Behav Physiol 7: $57-64$

Dauer DM (1973) Polychaete fauna associated with Gulf of Mexico sponges. Florida Sci 36: 192-195

Dauer DM (1974) Polychaete fauna associated with Gulf of Mexico sponges. Florida Sci 36: 192-195

Fauvel P (1939) Annélides Polychètes de l'Indochine recueilles par M. C. Dawidoff. Comm Pont Acad Sci 3 243-368

Gilpin-Brown JB (1969) Host-adoption in the commensal polychaete Nereis fucata. J Mar Biol Assoc UK 49 $121-127$

Glasby CJ, Watson C (2001) A new genus and species of Syllidae (Annelida: Polychaeta) commensal with octocorals. Beagle Rec N Terr Mus Art Sci 17: 43-51

Harris LH (2006) Re: $H$. bullocki feeding - or at least tasting. http://www.seaslugforum.net/find.cfm?id=17308 Sea Slug Forum, http://www.seaslugforum.net/find.cfm?id=17308, Australian Museum, Sydney

Hartman O (1954) Marine annelids from the northern Marshall Islands. US Geol Surv Prof Pap 260 Q: 615-644 Hartmann-Schröder G (1978) Einige Sylliden-Arten (Polychaeta) von Hawaii und aus dem Karibischen Meer. Mitt Hamburg Zool Mus Inst 75: 49-61

Humann P (1992) Reef Creature Identification. Florida, Caribbean, Bahamas. Vaughan Press, Orlando

Imajima M (1966) The Syllidae (polychaetous annelids) from Japan. IV. Syllinae. Publ Seto Mar Biol Lab 14 $219-252$

Imajima M (2003) Polychaetous Annelids from Sagami Bay and Sagami Sea collected by the Emperor Showa of Japan and deposited at the Showa Memorial Institute, National Science Museum, Tokyo (II): Orders included within the Phyllodocida, Amphinomida, Spintherida and Eunicida. Natl Sci Mus Monogr 23: 1-221

Imajima M, Hartman O (1964) The Polychaetous Annelids from Japan. Pt. I. Allan Hancock Found Spec Publ 26: $1-237$

Imamoto J (2002) Feeding in Hypselodoris festiva. Sea Slug Forum, http://www.seaslugforum.net/find.cfm?id=7858, Australian Museum, Sydney

Lattig P, San Martin G, Martin D (2007) Taxonomic and morphometric analyses of the Haplosyllis spongicola complex (Polychaeta: Syllidae: Syllinae) from Spanish seas, with re-description of the type species and descriptions of two new species. Sci Mar 71: 551-570

Lee JW, Rho BJ (1994) Systematic studies on Syllidae (Annelida, Polychaeta) from the South Sea and the East Sea in Korea. Korean J Syst Zool 10: 131-144

López E, Britayev TA, Martin D, San Martín G (2001) New symbiotic associations involving Syllidae (Annelida: Polychaeta), with some taxonomic and biological remarks on Pionosyllis magnifica and Syllis cf. armillaris. J Mar Biol Assoc UK 81: 399-409

Magnino G, Gaino E (1998) Haplosyllis spongicola (Grübe) (Polychaeta, Syllidae) associated with two species of sponges from east Africa (Tanzania, Indian Ocean). PSZN I: Mar Ecol 19: 77-87

Magnino G, Pronzato R, Sará A, Gaino E (1999) Fauna associated with the horny sponge Anomoianthella lamella Pulitzer-Finali \& Pronzato, 1999 (Ianthellidae, Deponpongiae) from Papua-New Guinea. Ital J Zoo 66: $175-181$ 
Martin, D. Aguado, M. T. \& Britayev, T. A. (2009) Review of the symbiotic genus Haplosvllides (Polychaeta, Syllidae), with description of a new species. Zoological Science 26: 646-655.

Maldonado M, Young CM (1998a) Limits on the bathymetric distribution of keratose sponges: a fied test in deep water. Mar Ecol Prog Ser 174: 123-139

Maldonado M, Young CM (1998b) Reevaluation of stalked aplysinid sponges, with description of a new species from the upper Bahamian slope. Bull Mar Sci 63: 417-426

Martin D, Britayev TA (1998) Symbiotic polychaetes: review of known species. Oceanogr Mar Biol Annu Rev 36: $217-340$

Martin D, Britayev TA, San Martín G, Gil J (2003) Inter-population variability and character description in the sponge associated Haplosyllis spongicola complex. (Polychaeta: Syllidae). Hydrobiologia 496: 145-162

Martin D, Marin I, Britayev TA (2008) Features of the first known parasitic association between Syllidac (Annelida, Polychaeta) and crustaceans. Organism Divers Evol 8: 279-281

Martin D, Núñez J, Riera R, Gil J (2002) On the associations between Haplosyllis (Polychaeta, Syllidae) and gorgonians (Cnidaria, Octocorallaria), with a description of a new species. Biol J Linn Soc 77: 455-477

Paola A, San Martín G, Martin D (2006) A new species of Haplosyllis Langerhans, 1879 (Polychaeta: Syllidae: Syllinae) from Argentina. Proc Biol Soc Wash 119: 346-354

Reiswig HM (1973) Population dynamics of Jamaican Demospongiae. Bull Mar Sci 23: 191-226

Rudman WB (2002) Comment on Re: Feeding in Hypselodoris festiva by Andrej Jaklin. Sea Slug Forum, http://www.seaslugforum.net/find.cfm?id=7896 Australian Museum, Sydney

Rudman WB (2006) Comment on Hypselodoris bullocki feeding - or at least tasting by Brian Francisco. Sea Slug Forum, http://www.seaslugforum.net/find.cfm?id=17283, Australian Museum, Sydney

Rullier F, Amoureux L (1979) Campagne de la Calypso au large des côtes Atlantiques de l'Amérique du Sud (1961-1962). I. 33. Annélides Polychètes. Ann Inst Océanogr Monaco 55: 145-206

San Martín G, Ibarzábal DR, Jiménez M, López E (1997) Redescription of Haplosyllides floridana Augener, 1924 (Polychaeta, Syllidae, Syllinae), with notes on morphological variability and comments on the generic status. Bull Mar Sci 60: 364-370

San Martín G, Nishi E (2003) A new species of Alcyonosyllis Glasby and Watson, 2001 (Polychaeta: Syllidae Syllinae) from Shimoda, Japan commensal with the gorgonian Melithaea flabellifera. Zool Sci 20: 371-375 Tsurumi M, Reiswig HM (1997) Sexual versus asexual reproduction in an oviparous rope-form sponge, Aplysina cauliformis (Porifera, Verongida). Invertebr Reprod Dev 32: 1-9

Uebelacker JM (1978) A new parasitic Polychaetous Annelid (Arabellidae) from the Bahamas. J Parasitol 64: $151-154$

Uebelacker JM (1982) Review of some little-known species of Syllides (Annelida: Polychaeta) described from the Gulf of Mexico and Caribbean by Hermann Augener in 1924. Proc Biol Soc Wash 95: 583-593

Velarde RG (2002) Re: Feeding in Hypselodoris festiva. Sea Slug Forum, http://www.seaslugforum.net/find.cfm?id=790, Australian Museum, Sydney
Martin, D. Asuado, M.T. \& Britayev, T. A. (2009) Review of the symbiotic genus Haplosyllides (Polychete Syllidae), with description of a new species. Zoological Science 26: 646-655.

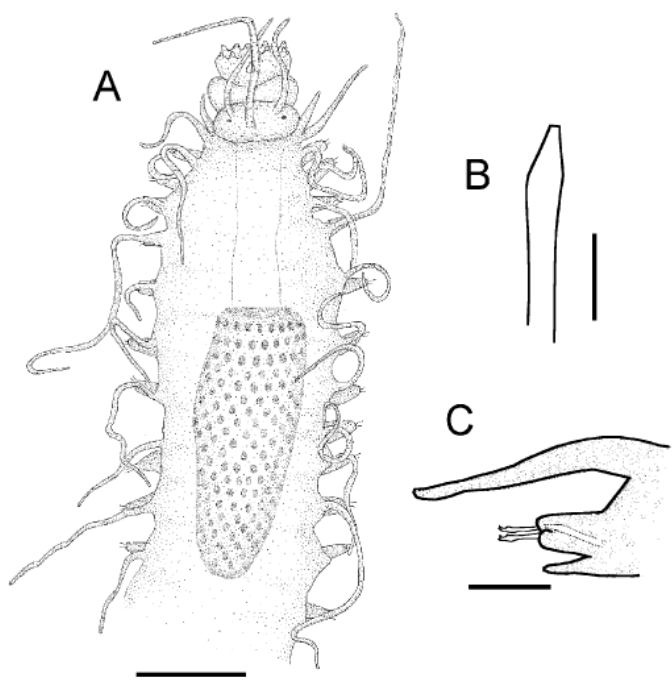

Fig. 1. Haplosyllides aberrans comb. nov. ZMA V. Pol. 2046. (A) Anterior part, dorsal view. (B) Midbody aciculum. (C) Midbody parapodium, anterior view; Scale bars, $0.5 \mathrm{~mm}$ (A), $0.1 \mathrm{~mm}$ (B), $20 \mu \mathrm{m}$ (C) 
Martin, D., Aguado, M T. \& Britayev, T. A. (2009) Review of the symbiotic genus Haplosyllides (Polychaeta, Syllide), with description of a new species. Zoological Science 26: 646-655.
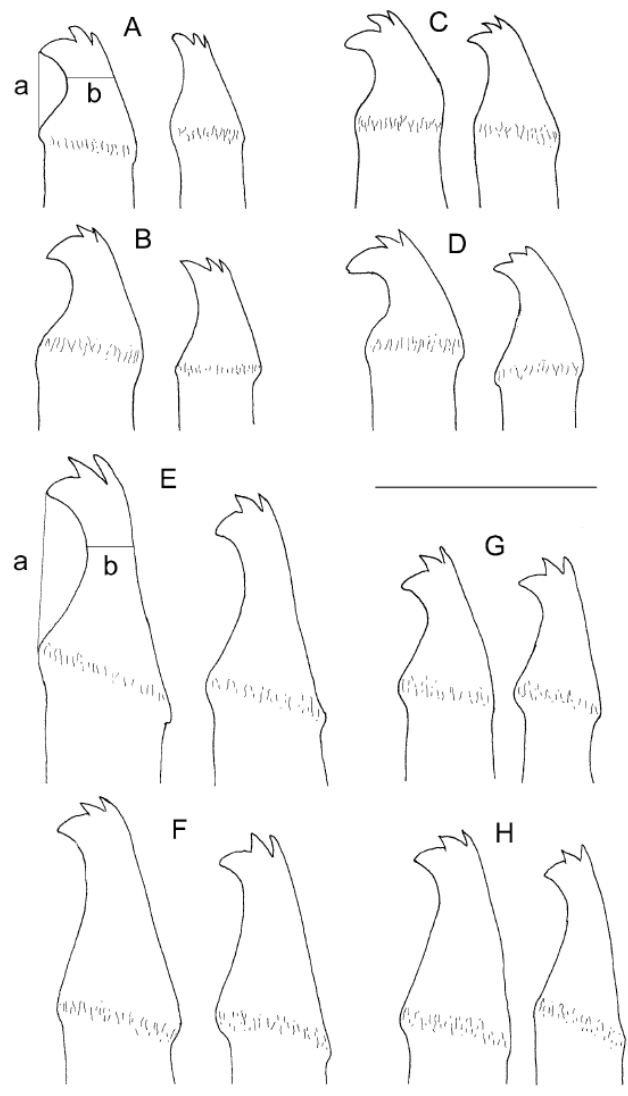

Fig. 2. (A-D) Haplosyllides floridana. (A) Anterior chaetae, form A, MNCNM 16.01/8810. (B) Posterior chaetae, form A, MNCNM 16.01/8810. (C) Anterior chaetae, form B, MNCNM 16.01/8808. (D) Posterior chaetae, form B, MNCNM 16.01/8808. (E) Haplosyllides aberrans comb. nov. (E) Anterior chaetae, specimen ZMA V. Pol. 2046. (F-H) Posterior chaetae, specimen ZMA V. Pol. 2046. (G) Anterior chaetae, specimen ZMA constriction; b, width of chaetal apex. Scale bar, $20 \mu \mathrm{m}$.
Martin, D. Aguado, M. T \& Britayev, T. A. (2009) Review of the symbiotic genus Haplosyllides (Polychaeta, Syllidae), with description of a new species. Zoological Science 26: 646-655.
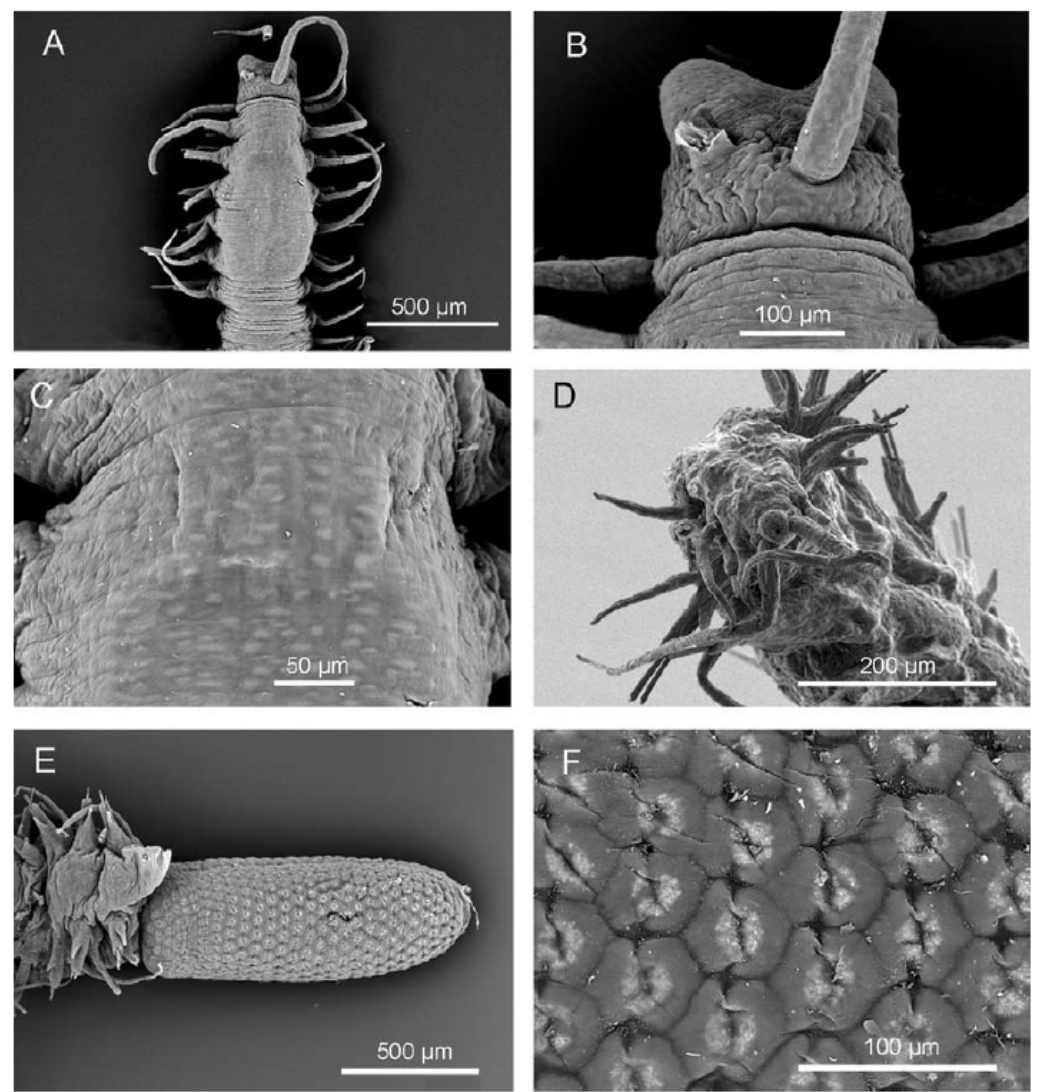

Fig. 3. Haplosyllides aberrans comb. nov. ZMA V.Pol. 5271. SEM. (A, B) Anterior end, dorsal view. (C) Midbody segments, dorsal view. (D) Posterior end. (E) Proventricle, ventral view. (F) Detail of muscle cell rows of proventricle. 
Martin, D. Aguado, M. T. \& Britayev, T. A. (2009) Review of the symbiotic genus Haplosyllides (Polychaeta, .
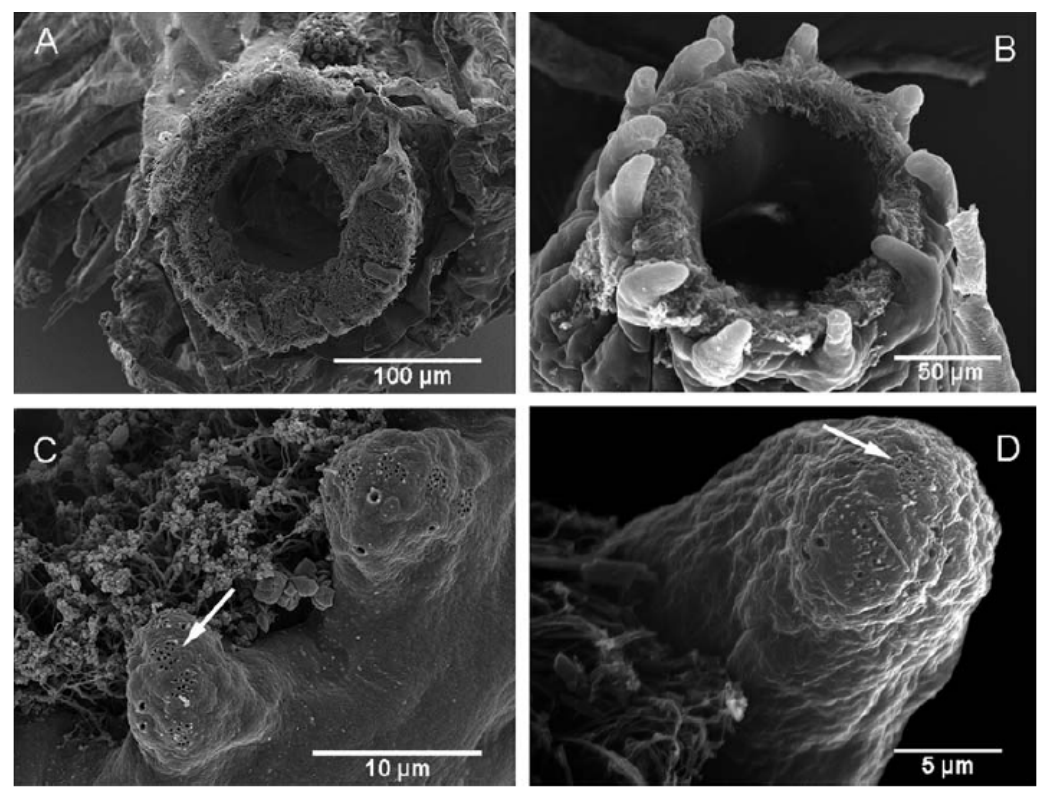

Fig. 4. Comparison between Haplosyl (C) Pharyngeal papillae and cilia, H. floridana, MNCNM 16.01/8806. (D) Pharyngeal papillae and cilia, $H$
Martin, D., Aguado, M. T. \& Britayev, T. A. (2009) Review of the symbiotic genus Haplosyllides (Polychaeta, Syllidae), with description of a new species. Zoological Science 26: 646-655.

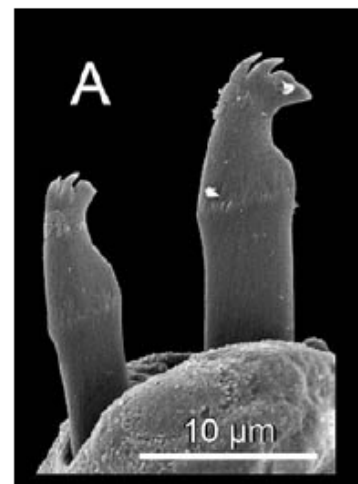

B

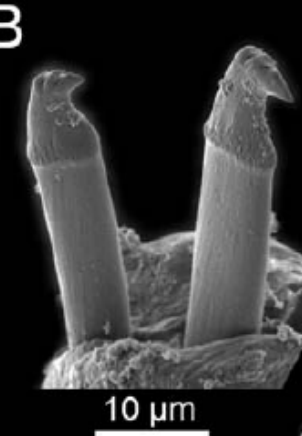

C
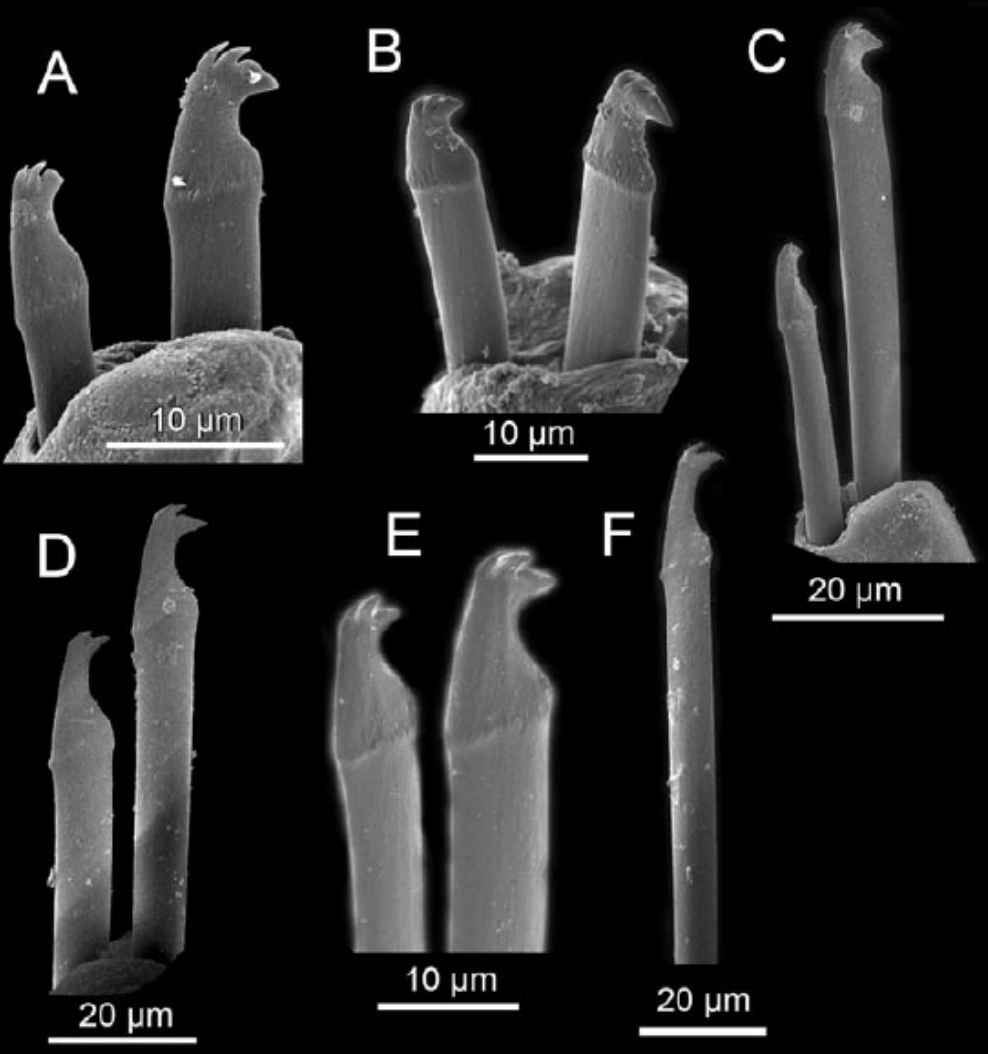

$\mathrm{E}$

$10 \mu \mathrm{m}$

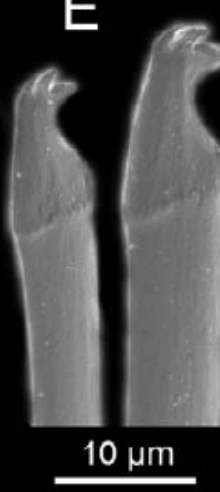

F

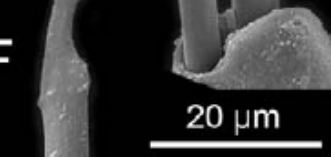

Fig. 5. Comparison between Haplosyllides floridana and Haplosyllides aberrans comb. nov. SEM (A-C) Haplosyllides floridana, MNCNM 16.01/8806. (A) Anterior chaetae. (B) Midbody chaetae. (C) Posterio chaetae. (D-F) Haplosyllides aberrans, ZMA V. Pol. 5271. (D) Anterior chaeta. (E) Midbody chaetae. (F) Posterior chaeta. 


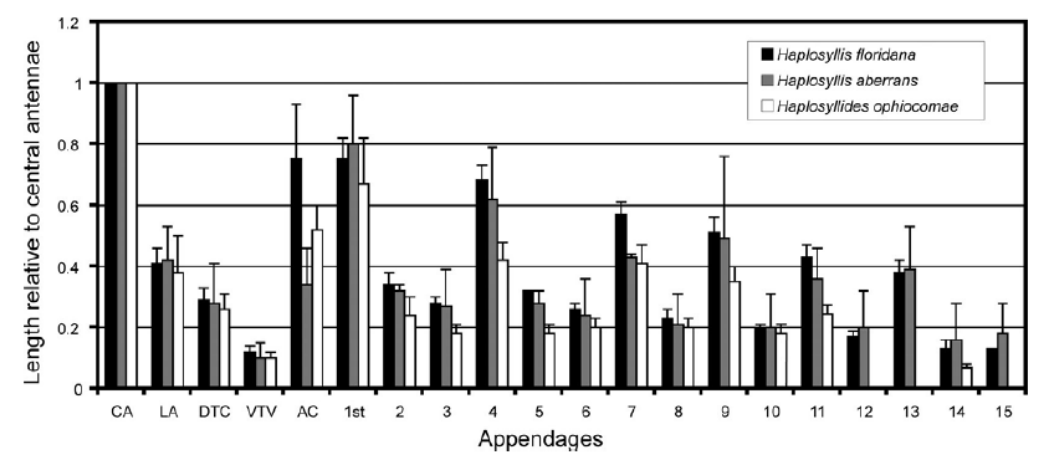

Fig. 6. Comparison of standardised appendage-length patterns among Haplosyllides floridana, Haplosyllides aberrans comb. nov., and Haplosyllides ophiocomae sp. nov. CA, central antennae; LA, lateral antennae; DTC,
Martin, D. Aguado, M. T \& Britayev, T. A. (2009) Review of the symbiotic genus Haplosyllides (Polychaeta, Syllidae), with description of a new species. Zoological Science 26: 646-655.
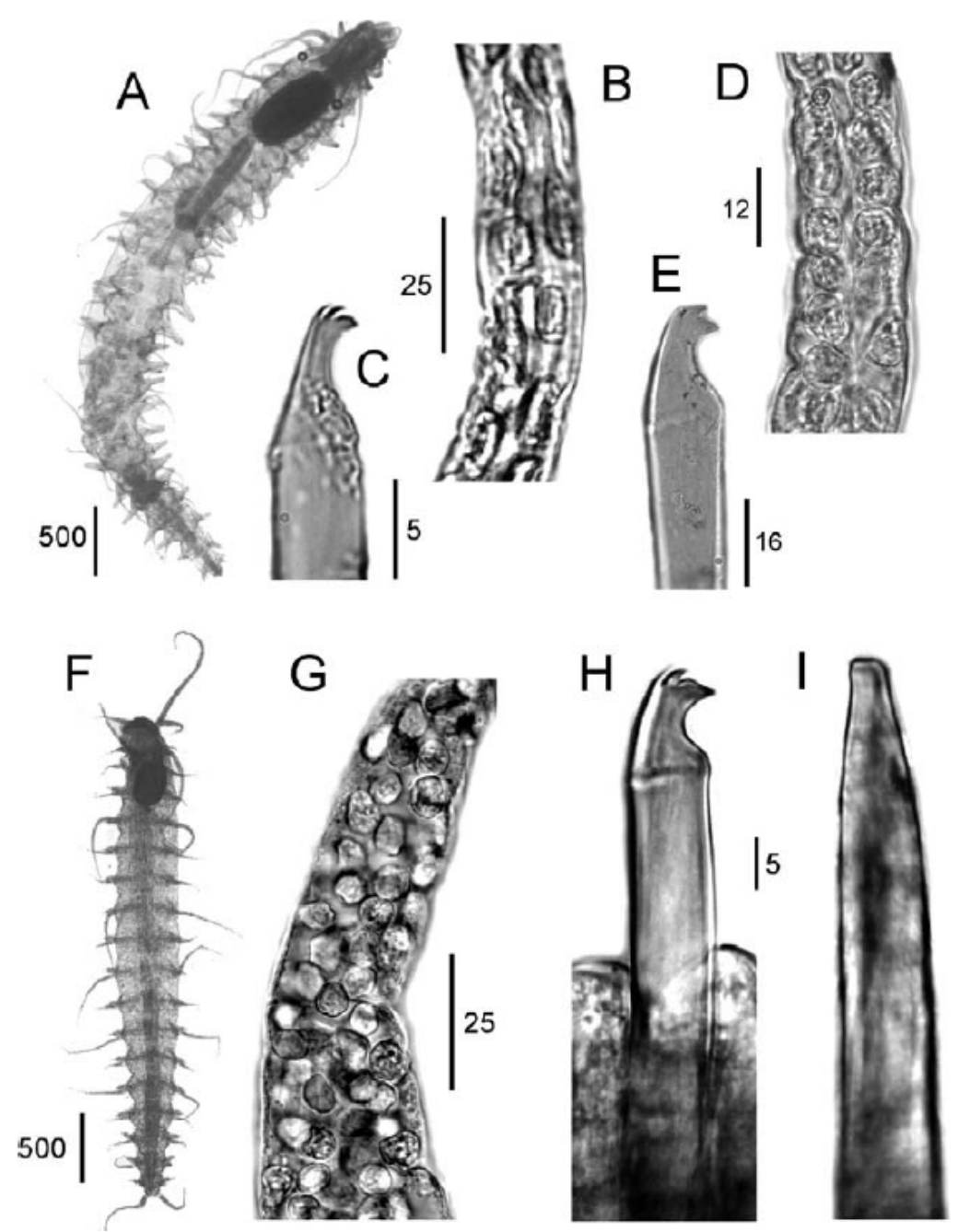

Fig. 7. (A-E) Haplosillides aberrans comb. nov., MNHNP POLY TYPE 0733. (A) Entire view of a syntype specimen. (B) Detail of granules inside a dorsal cirrus. (C) Mid-body chaeta, ZMA V. Pol. 2046. (D) Detail of (F) Entire view of a form-B specimen. (G) Granules inside a dorsal cirrus. (H) Mid-body chaeta. (I) Aciculum. The scale bars are in micrometers. 

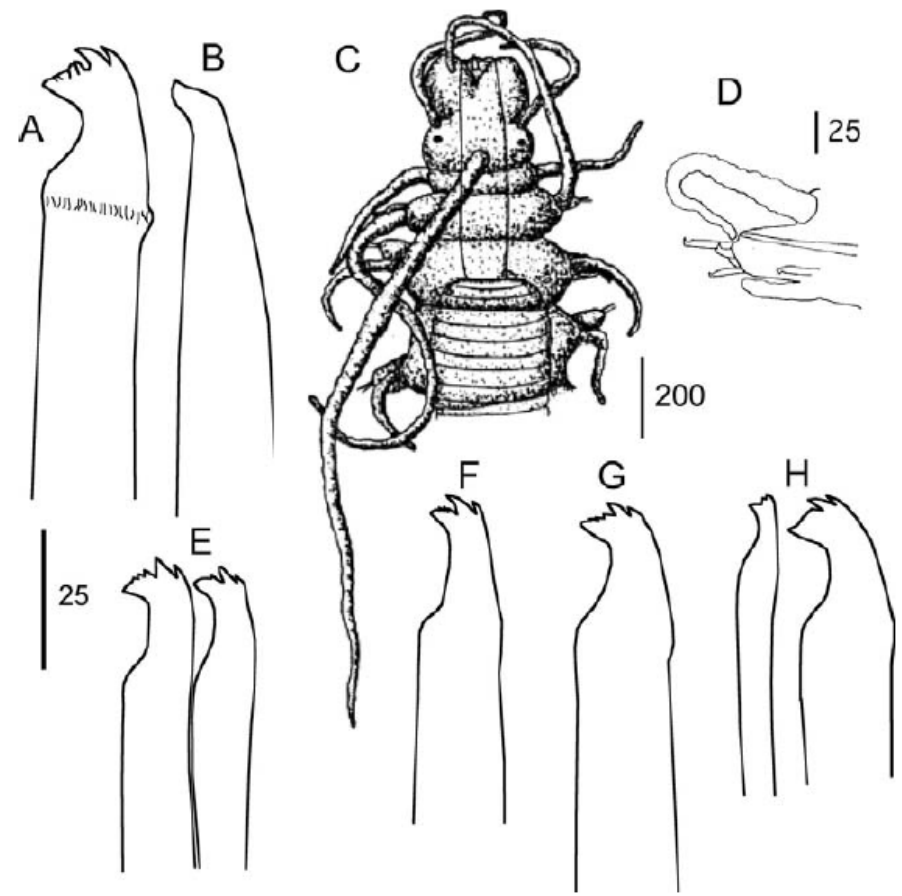

Fig. 8. Haplosyllides ophiocomae sp. nov. (A) Mid-anterior chaeta (holotype, ZMH P-22072). (B) Aciculum from a posterior chaetiger (holotype, ZMH P-22072). Paratype BPBM-R 917, redrawn from Hartmann-Schröder
(1978). (C) Anterior end. (D) Parapodium from segment 14. (E) Chaetae of segment 8. (F) Chaeta of segment 9 . (G) Chaeta of segment 10. (H) Chaetae of segment 14. The scale bars are in micrometers.
Martin, D. Aguado, M. T. \& Britayev, T. A. (2009) Review of the symbiotic genus Haplosyllides (Polychaeta, Syllidae), with description of a new species. Zoological Science 26: 646-655.

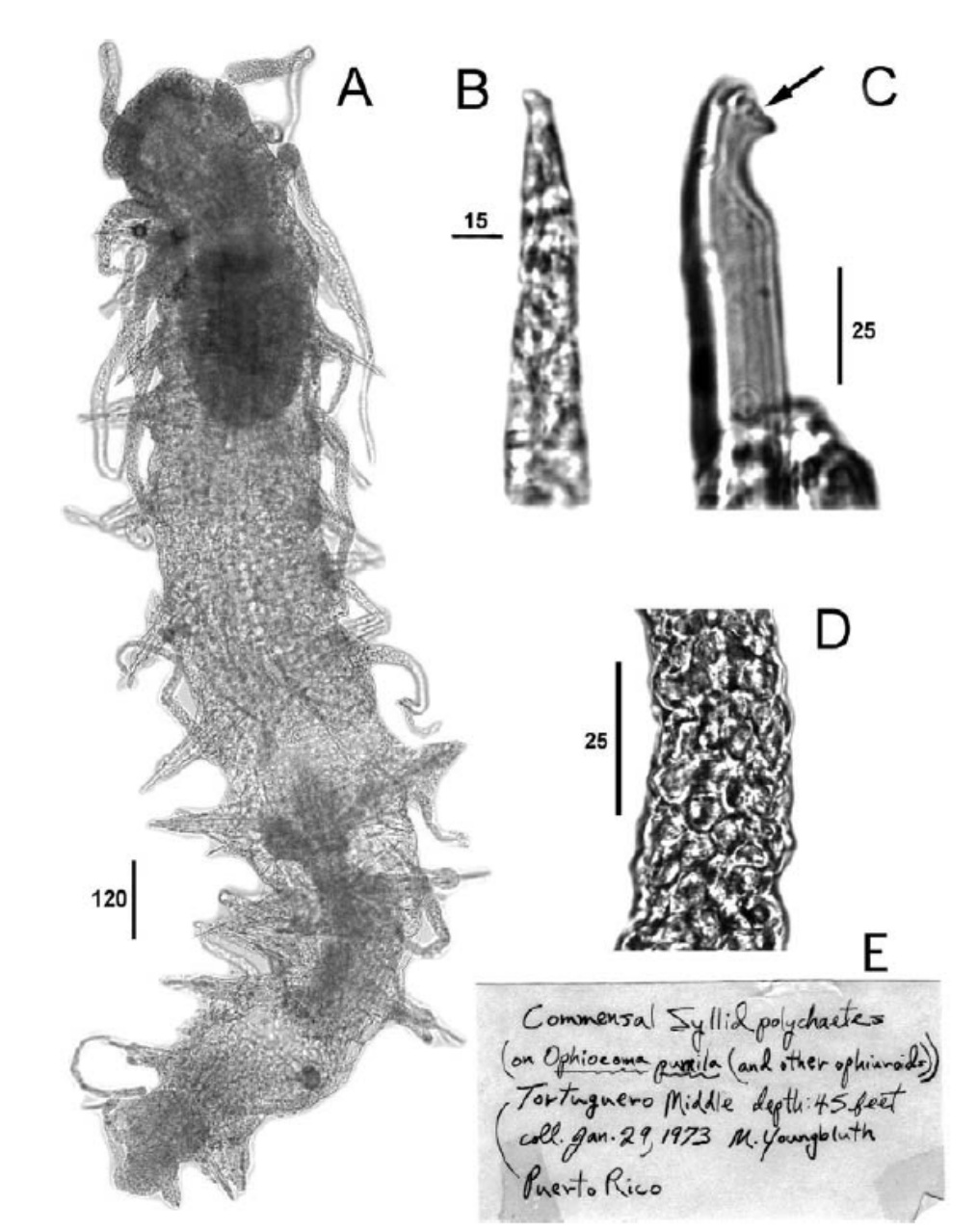

Fig. 9. Haplosyllides ophiocomae sp. nov., holotype, ZMH P-22072. (A) Entire view. (B) Aciculum. (C) Mid-

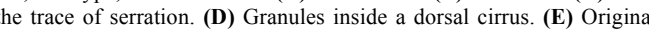
label for the paratypes at BPBM. The scale bars are in micrometers. 
Martin, D. Aguado, M. T. \& Britayev, T. A. (2009) Review of the symbiotic genus Haplosyllides (Polychaeta, Syllide), with description of a new species. Zoological Science 26: 646-655.

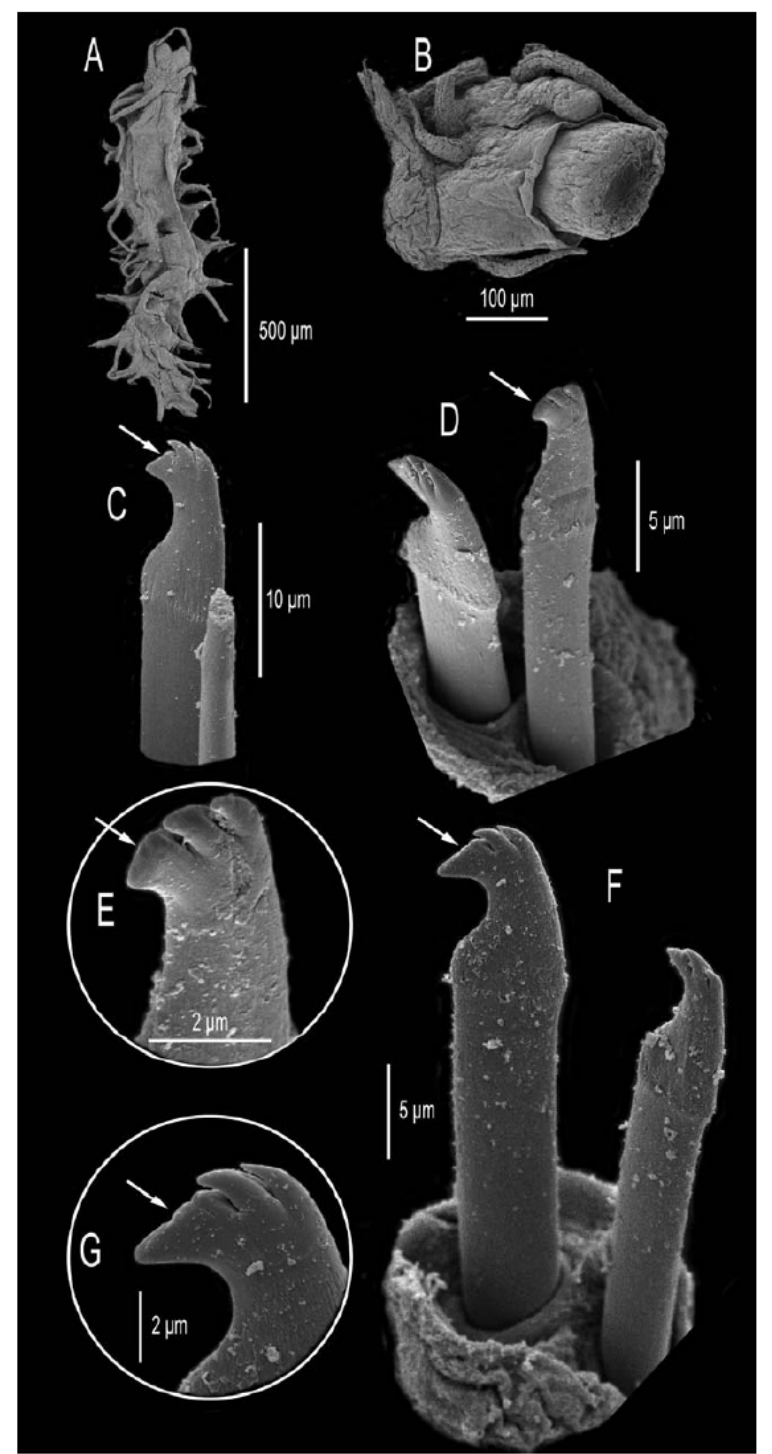

Fig. 10. Haplosyllides ophiociomae sp. nov. SEM. (A) Whole body, dorsal view. (B) Anterior end, ventral view. (C) Chaetae of chaetiger 1. (D) Mid-body chaetae. (E) Tip of mid-body chaeta. (F) Posterior chaetae. (G) Tip of
Martin, D., Aguado, M T. \& Britayev, T. A. (2009) Review of the symbiotic genus Haplosvllides (Polychaeta, Syllidae), with description of a new species. Zoological Science 26: 646-655.

Table 1. Summary of morphometric measurements for Haplosyllides floridana, H. aberrans comb. nov., and $H$. cirri; VTC, ventral tentacular cirri; AC, anal cirri; 1 to 26, dorsal cirri; avg, average; std, standard deviation.

\begin{tabular}{|c|c|c|c|c|c|c|}
\hline & \multicolumn{2}{|c|}{$\begin{array}{l}\text { Haplosyllides } \\
\text { floridana }\end{array}$} & \multicolumn{2}{|c|}{$\begin{array}{l}\text { Haplosyllides } \\
\text { aberrans comb. nov. }\end{array}$} & \multicolumn{2}{|c|}{$\begin{array}{l}\text { Haplosyllides } \\
\text { ophiocomae sp. nov. }\end{array}$} \\
\hline & avg & std & avg & std & avg & std \\
\hline Body length (mm) & 3.08 & 0.27 & 3.73 & 1.43 & 2.04 & 0.23 \\
\hline Body width WP (mm) & 0.36 & 0.05 & 0.50 & 0.15 & 0.30 & 0.08 \\
\hline mber of chaetigers & 14.33 & 0.58 & 20.33 & 4.93 & 15.00 & 5.66 \\
\hline Prostomium width (mm) & 0.21 & 0 & 0.28 & 0.08 & 0.23 & 0.07 \\
\hline Pharynx length $(\mathrm{mm})$ & 0.40 & 0.08 & 0.66 & 0.12 & 0.45 & 0.16 \\
\hline \multicolumn{7}{|l|}{$\begin{array}{l}\text { Proventricle } \\
\end{array}$} \\
\hline Muscular rows & 23.33 & 1.15 & 30.00 & 1.73 & 21.50 & 0.71 \\
\hline Length $(\mathrm{mm})$ & 0.40 & 0.06 & 0.58 & 0.12 & 0.47 & 0.28 \\
\hline Width $(\mathrm{mm}$ & 0.26 & 0.04 & 0.29 & 0.06 & 0.24 & 0.08 \\
\hline Length/width ratio & & 0.07 & 1.97 & 0.19 & 1.88 & 0.53 \\
\hline \multicolumn{7}{|c|}{ Length of appendages (in $\mathrm{mm}$ ) } \\
\hline CA & 0.98 & 0.07 & 1.25 & 0.27 & 1.15 & 0.62 \\
\hline LA & 0.40 & 0.04 & 0.51 & 0.07 & 0.40 & 0.09 \\
\hline DTC & 0.28 & 0.03 & 0.34 & 0.10 & 0.28 & 0.1 \\
\hline VTV & 0.12 & 0.02 & 0.12 & 0.04 & 0.07 & 0.03 \\
\hline$A C$ & 0.73 & 0.13 & 0.39 & 0.10 & 0.37 & 0.15 \\
\hline 1 & 0.74 & 0.04 & 1.02 & 0.20 & 0.72 & 0.24 \\
\hline & 0.33 & 0.02 & 0.40 & 0.07 & 0.25 & 0.07 \\
\hline & 0.27 & 0.01 & 0.34 & 0.11 & 19 & .08 \\
\hline & 0.66 & 0.02 & 0.79 & 0.21 & & 12 \\
\hline & 0.32 & 0.02 & 0.3 & 0.13 & & 05 \\
\hline & 0.26 & 0.01 & 0.29 & 0.08 & & 06 \\
\hline 7 & 0.55 & 0.02 & 0.5 & 0.14 & 9 & 12 \\
\hline 8 & 0.22 & 0.02 & 0.26 & 0.06 & 4 & 06 \\
\hline 9 & 0.50 & 0.02 & 0.59 & 0.20 & 25 & 04 \\
\hline 10 & 0.20 & 0.00 & 0.24 & 0.09 & 12 & .02 \\
\hline 11 & 0.42 & 0.02 & 0.47 & 0.16 & 0.19 & 0.08 \\
\hline 12 & 0.17 & 0.02 & 0.24 & 0.10 & - & - \\
\hline 13 & 0.37 & 0.03 & 0.43 & 0.12 & - & - \\
\hline 14 & 0.13 & 0.02 & 0.20 & 0.14 & - & - \\
\hline 15 & 0.12 & 0.00 & 0.21 & 0.10 & - & - \\
\hline 16 & - & - & 0.32 & 0.10 & - & - \\
\hline 17 & - & - & 0.22 & 0.10 & - & - \\
\hline 18 & - & - & 0.48 & 0.22 & - & - \\
\hline 19 & - & - & 0.25 & 0.04 & - & - \\
\hline 20 & - & - & 0.32 & 0.05 & - & - \\
\hline 21 & - & - & 0.31 & - & - & - \\
\hline 22 & 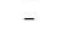 & - & 02 & - & 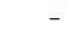 & - \\
\hline 20 & & - & & - & - & - \\
\hline 24 & - & - & 18 & - & - & - \\
\hline 25 & - & - & & - & - & - \\
\hline 26 & - & - & 0.10 & - & - & - \\
\hline
\end{tabular}

